\title{
МЕТОДОЛОГІЧНІ АСПЕКТИ ОЦІНКИ ЕКОЛОГІЧНОГО СТАНУ УРБАНІЗОВАНИХ І ТЕХНОГЕННО ЗМІНЕНИХ ТЕРИТОРІЙ
}

Запропоновано алгоритм здійснення біоіндикаційної оцінки екологічного стану урбанізованих і техногенно змінених територій. Виділено найінформативніші маркери урботехногенної напруги середовища на різних рівнях організації біосистем. Складено шкалу оцінки життсвості та біоіндикаційної перспективності рослин в умовах антропогенно трансформованих екотопів.

\section{В. И. Парпан, М. М. Миленькая}

Прикарпатский национальный университет им. Василия Стефаника

\section{МЕТОДОЛОГИЧЕСКИЕ АСПЕКТЫ ОЦЕНКИ ЭКОЛОГИЧЕСКОГО СОСТОЯНИЯ УРБАНИЗИРОВАННЫХ И ТЕХНОГЕННО ИЗМЕНЕННЫХ ТЕРРИТОРИЙ}

Предложен алгоритм проведения биоиндикационной оценки экологического состояния урбанизированных и техногенно измененных территорий. Выделены наиболее информативные маркеры урботехногенного напряжения среды на разных уровнях организации биосистем. Составлена шкала оценки жизненности и биоиндикационной перспективности растений в условиях антропогенно трансформированных экотопов.

\author{
V. I. Parpan, M. M. Mylenka \\ Vasyl Stefanyk Precarpathian National University
}

\section{METHODOLOGICAL ASPECTS OF THE EVALUATION OF ECOLOGICAL CONDITIONS OF URBANIZED AND ANTHROPOLOGICALLY ALTERED TERRITORIES}

Procedure of the evaluation of ecological conditions of the urbanized and anthropogenically altered territories is suggested. The most informative markers of the urboanthropolical tension of the environment at different levels of a biosystem organization are determined. Rating scale of the vital power and bioindicative prospectivity of plants under conditions of anthropologically transformed ecotopes is composed.

\section{Вступ}

Зростання антропогенного пресингу в міських екосистемах супроводжується техногенним забрудненням навколишнього середовища. Негативний вплив цього процесу проявляється деструктивними змінами у функціонуванні біотичних угрупувань, деградацією природних біотопів і погіршенням здоров’я людей [3].

Управління якістю навколишнього середовища вимагає оптимізаційних заходів і можливе лише за умови адекватної оцінки екологічного стану територій. Тому вдосконалення існуючої системи моніторингу довкілля та розробка нових високоефективних 
алгоритмів оцінювання рівня антропогенної трансформації екосистем - одне 3 актуальних завдань екології.

Багатокомпонентний характер реальних потоків забруднювачів не дозволяє об'єктивно оцінити екологічний стан урбанізованих і техногенно змінених екосистем лише на основі визначення концентрацій окремих інгредієнтів. За такого підходу не врахованими залишаються прямий кумулятивний вплив, синергічні взаємозв'язки між забруднювачами тощо. Об'єктивна оцінка можлива лише за умови поєднання класичних фізико-хімічних методів із біоіндикаційними, що $\epsilon$ основою системного екологічного принципу [8]. Організми-біоіндикатори та біотестори інтегрують біологічно значущі ефекти забруднення, дозволяють визначити шляхи надходження та місця накопичення в екосистемах різних токсикантів [2]. Вибір методик і об'єктів для біоіндикаційних досліджень потребує диференційного підходу та залежить від фізикогеографічних особливостей території; локалізації, типу та потужностей джерел техногенного впливу; рівня урбанізованості тощо.

\section{Матеріал і методи досліджень}

Матеріалом для побудови алгоритму здійснення комплексної інтегральної оцінки екологічного стану територій слугували результати попередніх моніторингових досліджень, виконаних протягом 1999-2009 рр. в умовах природних і урбопромислових екосистем Прикарпаття [8; 12]. Проведено аналіз і систематизацію існуючих методологічних підходів до оцінки рівня антропогенної трансформації екосистем $[1 ; 2 ; 5 ; 9]$.

\section{Результати та їх обговорення}

Першим і одним із найважливіших етапів проведення екологічного моніторингу $\epsilon$ науково обгрунтований вибір фонової (контрольної) території та методично правильне формування мережі моніторингових ділянок. Фонові території повинні бути екологічно чистими або близькими до них і мати сприятливі умови для життедіяльності живих істот [4]. Такими, переважно, $є$ території з особливим режимом охорони та використання природних ресурсів. Неодмінною умовою при цьому $\epsilon$ подібність досліджуваної та еталонної екосистем за кліматичними, едафічними та іншими особливостями. Моніторингова мережа повинна максимально репрезентувати досліджувану територію. У випадках, коли вивчається вплив конкретного підприємства на урбоекоситему, доречною $\epsilon$ побудова ситуативних картосхем розсіювання забруднювачів і подальше складання на їх основі координатної сітки спостережень.

Для міських територій характерна просторова неоднорідність екологічної напруги [8]. Це зумовлено відмінностями якісного та кількісного складу забруднювачів у межах функціональних зон (наприклад, доріг, селитебних зон або промислових площадок). 3 іншого боку, окремим таксономічним одиницям міського ландшафту притаманні відмінні мікрокліматичні, фізико-географічні, архітектурно-планувальні та інші особливості, що може мати істотний вплив на процеси міграції та акумуляції екотоксикантів у довкіллі. Тому для оцінки екологічної ситуації у місті доцільне формування моніторингової мережі за функціональною класифікацією урболандшафтів. У випадку монофункціональних урбоекосистем такий підхід дозволяє врахувати внесок різних антропогенних чинників у екологічний стан території.

Характерна особливість урбопромислових екосистем - зростання генетичної напруги середовища, що зумовлено систематичним надходженням в екотопи полютантів із вираженою мутагенною активністю. Для просторової характеристики сукупного впливу мутагенів різної етіології зручним $€$ використання поняття «токсико- 
мутагенний фон», яке враховує розповсюдженість мутагенного впливу, його тривалість і вираженість мутагенних ефектів. Ідеальною системою еколого-генетичного моніторингу є практика виявлення всіх типів мутацій в організмів на різних рівнях організації [5].

Пошук і застосування різнорівневих біомоніторів із наступною екстраполяцією отриманих результатів на популяційні процеси можна вважати найперспективнішим напрямом у системі біомоніторингу. Мутагенний фон установлюється за значенням інтегрального показника ушкодженості біоіндикаторів, який враховує часткові показники генних, хромосомних і функціональних порушень і визначає рівні екологічної небезпеки для людини та біоти. Запропонований метод покладений в основу уніфікованої оцінкової шкали, що характеризує стан об’єктів довкілля за токсикомутагенним фоном [10].

На сьогодні описано понад сотню тест-методів для виявлення генотоксичності, які проводять на біооб'єктах різних таксономічних рангів - від бактеріофагів до ссавців. Усі ці методи базуються на ідентифікації певних типів генетичних пошкоджень. Вони відрізняються чутливістю й екстраполятивністю отриманих результатів із одних тест-об'єктів на інші та людину. Останнє пов'язане з відмінностями організації спадкового апарату у різних біологічних видів [6].

При моніторингових дослідженнях важливе дотримання фундаментального принципу простоти аналізу: найефективніші методи індикації з використанням простих тестів, які дозволяють швидко оцінити екологічний стан великих територій малою кількістю людських та інших ресурсів [2; 15]. Тому у практичній роботі добре зарекомендували себе рослинні тест-системи, особливо тест з Allium сера, у якому як матеріал використовують первинні або додаткові корінці ріпчастої цибулі (Allium cepa L.). Він дає можливість вивчити гено- та цитотоксичність середовища та документувати результати мікроскопічними дослідженнями хромосомних і ядерних аномалій $[6 ; 13]$.

Урбопромислові забруднювачі не лише володіють загальнотоксичним впливом на біоту, а й здатні спричинювати так звані «віддалені наслідки», зокрема, проявляти гаметоцидну дію [1; 14]. Особливо цінні дослідження гаметоцидних властивостей полютантів виконані в умовах in situ, оскільки фактичний мутагенний потенціал полютантів у довкіллі може істотно відрізнятися від виявленого за допомогою лабораторного скринінгу. Тому перспективним підходом в індикації мутагенної напруженості навколишнього середовища $є$ дослідження репродуктивних структур вищих судинних рослин, насамперед чоловічого гаметофіту. Більшість індукованих полютантами мутацій $є$ рецесивними й проявляються в гаплоїдних пилкових клітинах чи зародках при ембріональному розвитку насіння. Мейоз виконує роль своєрідного бар'єру у передачі потомству деяких типів таких мутацій, у результаті чого утворюється стерильний пилок і нежиттєздатне насіння [1]. Таким чином, найвагомішими критеріями в оцінці дії урботехногенних забруднювачів $є$ кількість аномальних мейотичних клітин і стерильність пилкових зерен. Найпоширенішим методом визначення стерильності пилку $\epsilon$ виявлення безкрохмальних пилкових зерен. Проте наявність крохмалю не гарант життєздатності, оскільки процес інгібування проростання пилкової трубки може бути зумовлений порушенням синтезу будь-якої іншої біологічно активної речовини. 3 іншого боку, пилкові зерна, які несуть спермії, не завжди фертильні, навіть якщо вони містять крохмаль. Для об'єктивної оцінки гаметоцидності комплексу урботехногенних факторів, доцільним є виявлення інгібіції процесів проростання пилку та росту пилкової трубки [9]. Експериментальними дослідженнями виявлена пряма залежність між дозою ряду хімічних агентів, кількістю аберацій у мейозі та стерильністю й 
діаметром пилку [1; 9]. Тому морфометричні аномалії пилкових зерен можуть слугувати інформативною додатковою біоіндикаційною ознакою при еколого-генетичних дослідженнях [16].

Отже, для характеристики екологічного стану урбоекосистем за токсикомутагенним фоном можна запропонувати логічну схему ії здійснення (рис. 1).

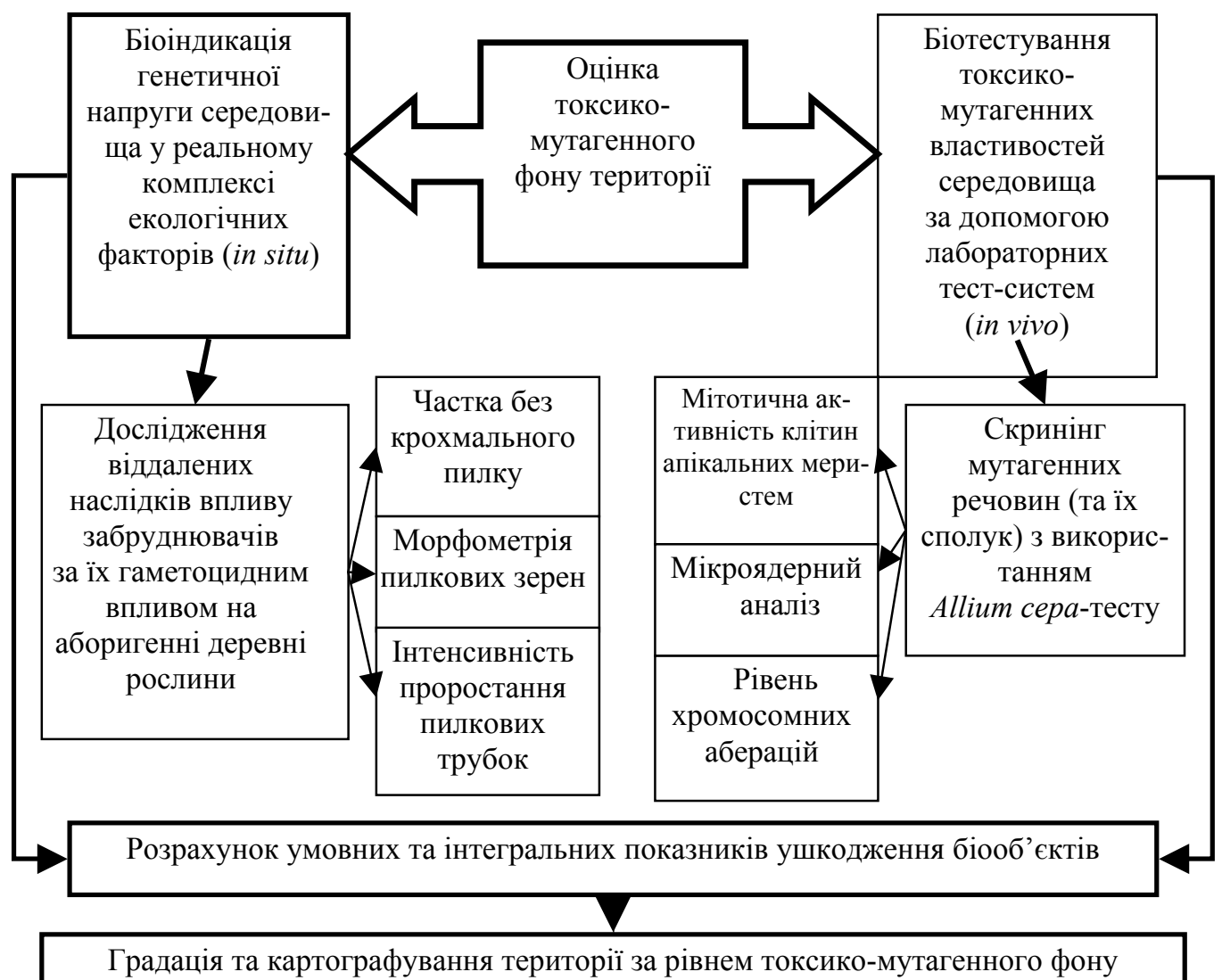

Рис. 1. Алгоритм оцінки токсико-мутагенного фону територій

Цінними індикаторними властивостями володіють деревні рослини, які входять у комплекси озеленення підприємств і міських вулиць. Унаслідок тривалої експозиції в антропогенно змінених умовах середовища існування вони здатні відображати хронічний вплив малих доз інгредієнтів промислових викидів.

Вплив урботехногенних полютантів проявляється зміною інтегральних показників фітовітальності та формуванням пристосувально-захисних механізмів рослин. В основі адаптаційної здатності рослинних організмів до дії стресових чинників лежить зміна низки морфофізіологічних параметрів листків. Вони індикують ранні порушення біологічних систем, характеризують стан асиміляційного апарату у досліджуваних умовах і є одними з найінформативніших показників якості середовища [1].

Інтегральна оцінка екологічного стану територій повинна включати дослідження біоіндикаторів на різних рівнях організації: від молекулярного до екосистемного. Завдяки такому підходу відкриваються шляхи для виявлення й оцінки комплексних стресових впливів усіх недиференційованих факторів навколишнього середовища на 
біологічні системи. Пошкоджувальні ефекти на нижчих рівнях часто нівелюються на більш високих, і тому не завжди виявляються через видимі фізіологічні реакції організмів, хоча й можуть відігравати суттєву роль у спадкових і відтворювальних процесах у віддаленіший період дії екотоксикантів [2].

За результатами попередніх досліджень виділено найінформативніші біоіндикаційні ознаки, рекомендовані до застосування при біомоніторингових дослідженнях урбанізованих і техногенно змінених екосистем (рис. 2).

\begin{tabular}{|c|c|}
\hline \multirow{3}{*}{ Молекулярний рівень } & $\begin{array}{l}\text { Стан фотосинтетичної системи } \\
\text { (вміст хлорофілу } a \text {, хлорофілу в та каротиноїдів) }\end{array}$ \\
\hline & $\begin{array}{l}\text { Особливості нітрогенного обміну } \\
\text { (вміст білкового, небілкового та загального нітрогену) }\end{array}$ \\
\hline & $\begin{array}{l}\text { Внутрішньоклітинні концентрації «стресових сполук» } \\
\text { (наприклад, вільного проліну) }\end{array}$ \\
\hline
\end{tabular}
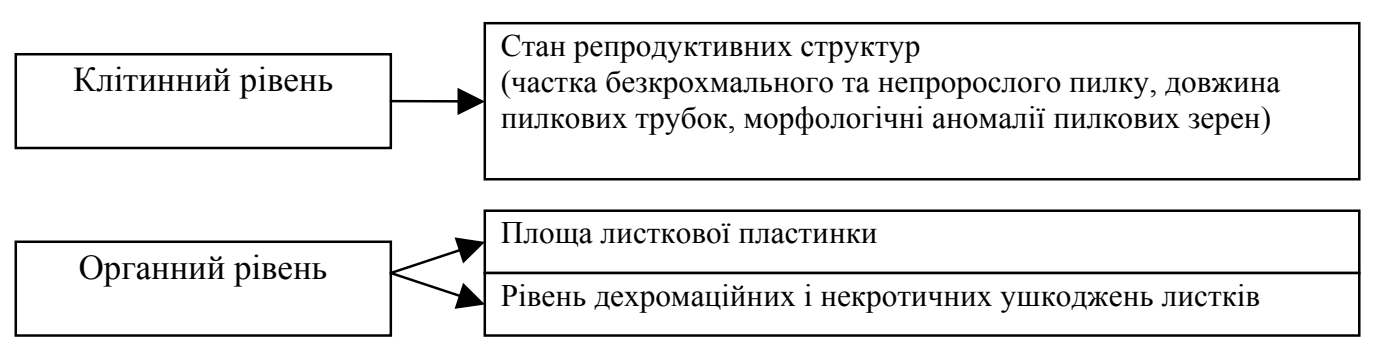

\begin{tabular}{|c|} 
Організмово- \\
популяційний рівень
\end{tabular}

\begin{tabular}{|l|l|}
\hline Екосистемний рівень & $\begin{array}{l}\text { Продуктивність у кормових мережах } \\
\text { (наприклад, нітрогену та зольних елементів) }\end{array}$ \\
\hline
\end{tabular}

Рис. 2. Біоіндикаційні ознаки деревних рослин на різних рівнях організації біосистем

Зазначені показники 3 успіхом можуть використовуватись також як критерії стійкості рослин до дії урботехногенних чинників при створенні екологоефективних культурфітоценозів у містах.

Оскільки кожен із рекомендованих біомаркерів - кількісна величина, можна запропонувати таку шкалу оцінки біоіндикаційної перспективності та життєвості рослин в умовах антропогенно трансформованих екотопів (табл.).

Таблиия

Шкала оцінки біоіндикаційної перспективності та життєвості рослин в умовах урбопромислових екосистем

\begin{tabular}{|c|c|c|}
\hline $\begin{array}{c}\text { Відхилення показника } \\
\text { від контрольного (фонового) значення }\end{array}$ & Категорія стійкості виду & $\begin{array}{c}\text { Біоіндикаційна } \\
\text { перспективність виду }\end{array}$ \\
\hline$<10 \%$ & \multirow{2}{*}{ висока } & неможливий індикатор \\
\cline { 1 - 3 } сунумівний індикатор \\
\hline $30-50 \%$ & середня & допустимий індикатор \\
\hline$>50 \%$ & низька & надійний індикатор \\
\hline
\end{tabular}


Важливою складовою інтегральної оцінки екологічного стану урбанізованих і техногенно змінених територій є кумулятивна індикація, в основу якої покладено здатність рослин змінювати хімічний склад апроксимаційно геохімічним чи аеральним особливостям середовища існування. Акумулятивну здатність деревних рослин найкращим чином характеризує мікроелементний склад листкового опаду $[11 ; 12 ; 17]$. Кількісною мірою рівня забруднення територій та індикаційної перспективності виду можуть слугувати коефіцієнт аномальності (відношення концентрації мікроелемента в опаді на дослідній ділянці до фонового показника) та коефіцієнт біологічного поглинання (відношення концентрації мікроелемента в опаді до його концентрації у грунті).

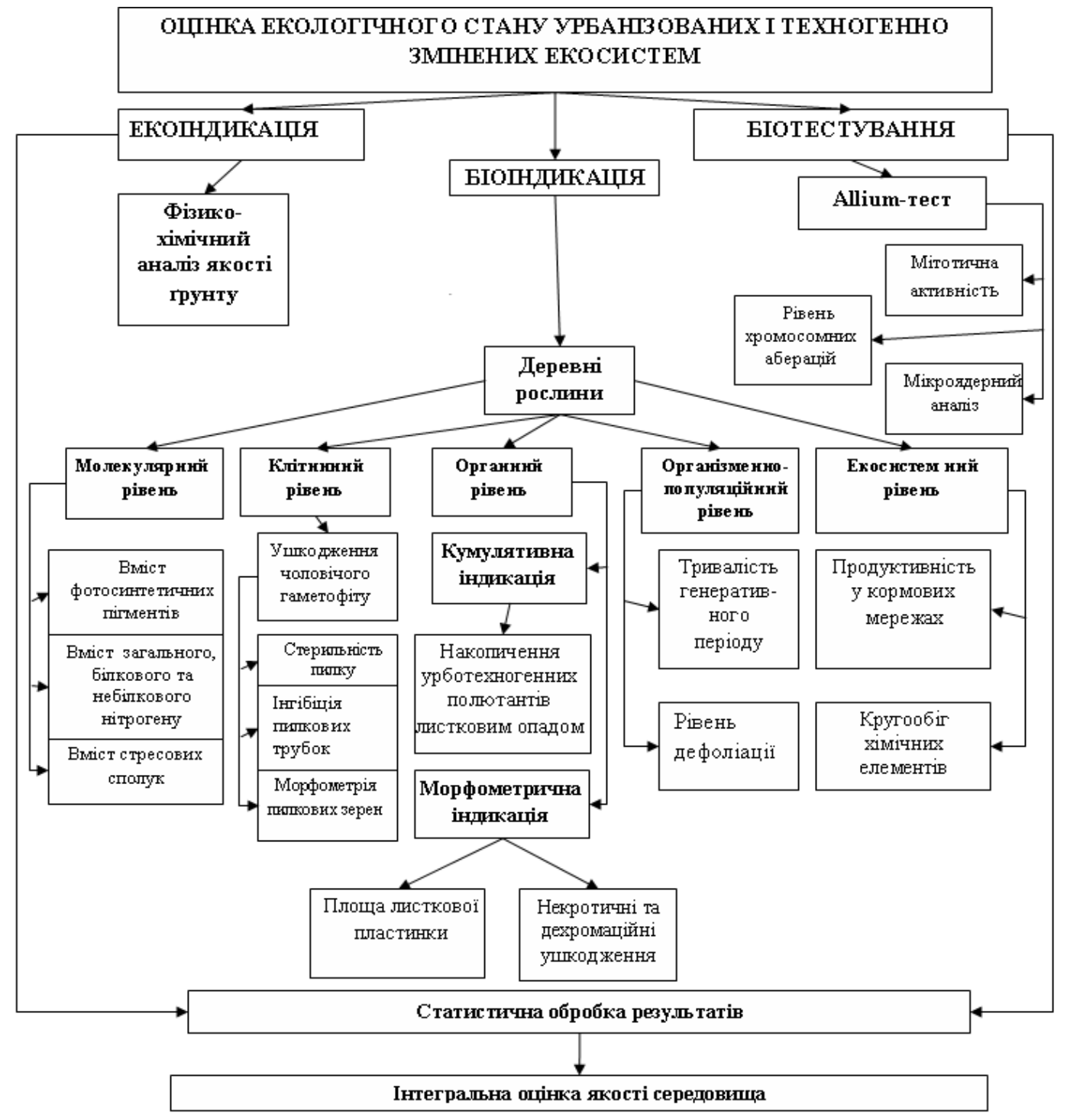

Рис. 3. Алгоритм здійснення комплексної інтегральної оцінки екологічного стану урботехногенних екосистем

Підсумковим етапом здійснення інтегральної оцінки екологічного стану територій $є$ встановлення кореляційно-регресійних залежностей між зміною біоіндикацій66 
них показників та рівнем забруднення довкілля урботехногенними полютантами. Це дозволяє не лише виокремити найістотніший фактор впливу, а й виділити найінформативніші біоіндикаційні ознаки в умовах конкретних екосистем. Характер зв'язку між аналізованими параметрами відображають рівняння регресії, які можуть слугувати основою для моделювання та прогнозування можливих змін у біоценозах за дії урботехногенних факторів. Перспективною $є$, при цьому, практика побудови комп'ютерних моделей [12]. У цілому, можна запропонувати алгоритм здійснення інтегральної оцінки екологічного стану урбанізованих і техногенно змінених територій (рис. 3). Такий підхід до оцінки екологічного стану урбопромислових екосистем дозволяє врахувати комплексний вплив факторів на біотичні угрупування та може бути рекомендований для впровадження у систему екологічного моніторингу довкілля.

\section{Висновки}

Об'єктивна та повна оцінка екологічного стану урбопромислових екосистем можлива за умови поєднання класичних фізико-хімічних методів із біоіндикаційними. Застосування різнорівневих біоіндикаторів $\epsilon$ найперспективнішим напрямом у системі екомоніторингу. На кожному рівні організації біосистем виділяються найінформативніші біоіндикаційні ознаки, які можуть слугувати критеріями стійкості рослин до дії урботехногенних чинників. Використання деревних рослин як біоіндикаторів якості довкілля та акумуляторів урботехногенних полютантів - необхідна передумова створення екологоефективних культурфітоценозів у містах.

Оцінка токсико-мутагенного фону територій повинна включати лабораторний скринінг із використанням рослинних тест-систем і біоіндикацію генетичної напруги в умовах in situ шляхом установлення гаметоцидного впливу на деревні рослини.

Встановлення регресійних залежностей між зміною біоіндикаційних показників та рівнем забруднення довкілля - основа для моделювання та прогнозування можливих змін у біоценозах за дії урбогенних чинників.

\section{Бібліографічні посилання}

1. Бессонова В. П. Морфофункциональные исследования растений в условиях загрязнения среды тяжелыми металлами: Автореф. дисс. ... д-ра биол. наук. - Д. : ДГУ, 1991. - 36 с.

2. Биоиндикация загрязнений наземных экосистем / Под ред. Р. Шуберта. - М. : Мир, 1988. $350 \mathrm{c}$.

3. Голубець М. А. Екосистемологія. - Львів : Поллі, 2000. - 316 с.

4. Горова А. І. Про можливість використання цитогенетичних методів біоіндикації при виборі контрольних територій в системі екомоніторингу / А. І. Горова, В. Ю. Грунтова, А. В. Павличенко // Наук. вісник Чернівецького ун-ту. - 2008. - Вип. 416: біологія. - С. 3-8.

5. Методологические аспекты оценки мутагенного фона и генетического риска для человека и биоты от действия мутагенных экологических факторов / А. И. Горовая, Л. Ф. Бобырь, Т. В. Скворцова и др. // Цитология и генетика. - 1996. - Т. 30, № 6. - С. 78-86.

6. Захаров В. М. Биотест: интегральная оценка здоровья экосистем и отдельных видов / В. М. Захаров, Д. М. Кларк. - М. : Биотест, 1995. - 68 с.

7. Козак I. I. Екологічне моделювання із використанням програми Stella / I. I. Козак, В. I. Парпан. Івано-Франківськ : Плай, 2009. - 214 с.

8. Миленька М. М. Біоіндикаційна оцінка екологічного стану Бурштинської урбоекосистеми: Автореф. дис. ... канд. біол. наук. - Д. : ДНУ, 2009. - 23 с.

9. Морозова Т. В. Комплексна біоіндикаційна оцінка екологічного стану слабоурбанізованих селитебних територій Чернівецької області: Автореф. дис. ... канд. біол. наук. - Чернівці : ЧНУ, 2004. -25 c. 
10. Наказ МОЗ України № 116 від 13.03.2007 р. “Про затвердження методичних рекомендацій «Обстеження та районування території за ступенем впливу антропогенних чинників на стан об’єктів довкілля з використанням цитогенетичних методів»” // Офіційний вісник України. 2007. - № 4. - С. 186-209.

11. Парпан В. І. Деревні рослини як кумулятивні індикатори забруднення довкілля важкими металами / В. І. Парпан, М. М. Миленька // Наук. зап. Тернопільського нац. пед. ун-ту. - 2008. № 4 (38). - C. 93-97.

12. Парпан В. І. Оцінка техногенного впливу на стан природних екосистем методами інтегрального моніторингу та біогеохімічної індикації лісів на прикладі Івано-Франківської області / В. І. Парпан, Ю. С. Шпарик, М. М. Миленька // Наук. вісн. НУБіП України. Лісівництво. Декоративне садівництво. - 2009. - Вип. 135. - С. 22-31.

13. Fiskesj G. Allium test// Methods in Molecular Biology - 43. in vitro Toxicity Testing Protocols / Ed. S. o'Hare, C. K. Atterwill. - Totowa, NJ : Humana Press Inc., 1995. - P. 119-127.

14. Johnson F. M. The genetic effects of environmental lead // Mutat. Res. - 1998. - Vol. 410, N 2. P. 123-129.

15. Müller M. Die Anwendung der «Cytogenetischen Bioindication» zur Früherkennung von Vegetationsschädens in der Steiermark / M. Müller, H. Guttenberg, D. Grill // Mitt. Naturwiss. Ver. Steiemark. - 1991. - B. 121. - S. 43-50.

16. Mylenka M. The woody plants pollen anomality under the conditions of the urbotechnogenic ecosystem / M. Mylenka, V. Parpan // XII Dni Alergii Pylkowej w Krakowie. Konferencija Naukowo-Szkoleniowa. - Krakow, 2010. - S. 21-24.

17. Chemical and morphological changes in Carpatian mountains trees caused by air pollution / V. Parpan, B. Maňkovska, M. Černŷ et al. // Effects of Air Pollution on Forest Health and Biodiversity in Forests of the Carpatian Mountains. NATO Science Series: Life and Behavioural Sciences. - 2002. - Vol. 345. - P. 173-213.

Надійшла до редколегії 12.09.2010 